\title{
THE ANALYSIS OF STUDENTS' DIFFICULTIES IN WRITING RECOUNT TEXT
}

\author{
Khairunnisaak, Dewi Sartika, Rekha Asmara \\ Program Studi Pendidikan Bahasa Inggris FKIP \\ Universitas Islam Ogan Komering Ilir Kayuagung \\ Email:khumairahnisaa@gmail.com,dewisartika@uniski.ac.id,rekha_asmara@gmail.com
}

Revised: 18 November 2021

doi: 10.26418/jeep.v3i1.50496
Accepted: 11 January 2022

Online Published: 22 January 2022

URL: http:/ / dx.doi.org/10.26418/jeep.v3i1.50496

\begin{abstract}
As a crucial skill, writing is significant to be studied comprehensively. However, some students had problems expressing their experiences in the written form. Therefore, the purpose of this research was to explain difficulties faced by the eighth graders of SMP Bait Qur'an in writing a recount text. Descriptive qualitative was used to investigate this research. To obtain the data, a written test and a questionnaire were applied. To analyze the obtained data, data reducing, data displayed, content analysis, and drawing a conclusion were applied. Then the data were analyzed using percentage analysis. The test results showed that most students had poor ability in writing a recount text. It could be seen that 12 students (54.54\%) were very poor in writing content of the recount text, 15 students (68.18\%) were very poor in the organization of the recount text, 12 students (54.54\%) were very poor in the vocabulary of the recount text, 19 students $(86.37 \%)$ were very poor in the grammar of the recount text, and 16 students (72.72\%) were very poor in the mechanic of the recount text. Most students had difficulties understanding grammar use in a recount text. It happened because they were lack of knowledge about the recount text itself and less practice writing a recount text.
\end{abstract}

Key words: writing, a recount text, difficulty

To cite this paper (in APA style):

Khairunnisaak, Sartika, D., \& Asmara, R. (2022). The analysis of students' difficulties in writing recount text. Journal of English Education Program, 3(1), 59-66.

\section{INTRODUCTION}

Writing has a significant role for students in the language learning process. As stated by Sapkota (2012, p.70), "Writing is defined as "a process of putting down pictorial symbols that serve to create a language to transmit some meaning to the reader so that he or she can absorb information that the writer has attempted to impart. Bazir (2016, p. 169) also explains that writing has a procedure requiring ideas, thinking, vocabulary, grammar, punctuation, and expressing those ideas. It meant that writing is a way to deliver ideas using words, sentence structures, mechanics, and punctuation so that the utterances have meaning and can be understood by readers.

Furthermore, Brink (2020, p.1) explains that writing is important to be learned because of some reasons. First, writing is a life skill, not only an essential job-related skill because it is 
often utilized by others judge to evaluate your learning, values, ideas, and contribution to society. Second, writing is a very personal activity. Even after our deaths, writing expresses who we are. It permits others to observe our knowledge, ambitions, and future work. Writing is the meant to explain our ideas to ourselves and to others while preserving our personal experiences and our memories. Third, writing enables someone to achieve a far broader audience over time and in many different places. To put it another way, writing can help students enhance their life skills while also encouraging many people to become readers.

One of the texts that has got to be learned by secondary school students is recount text. supported Harris, Ansyar, and Radjab (2014, p. 56), recount text refers to text telling experiences in the past. A recount is commonly to entertain by addressing a sequence of events that builds a link between a writer/reader and a speaker/listener, in line with Hyland cited in Azhar (2015, p.26). A recount could be a social genre that retells events with the intention of enlightening or entertaining the audience. The past tense is utilized in the recount text. A recount's social goal is to rebuild prior experiences by retelling them in their original order. In other terms, a recount text is a text that discusses past occurrences in chronological sequences, such as diaries, to inform or entertain the reader.

Students sometimes struggle when it comes to creating recall material. It was backed up by Za'in (2017, p.56), who discovered that most students struggled with five aspects of recount text writing: content, organization, vocabulary, language, and mechanics. It occurred as a result of grammatical inadequacies, a lack of knowledge and understanding, a lack of experience, and a lack of educational background. Sari (2017, p.1) also claims that most students struggle with capitalization, punctuation, inexplicitness/fuzziness, organization/illogical sequencing, spelling, and grammatical issues when producing recount texts. It may be deduced that most students struggle to write recount texts due to a lack of ideas, a lack of order or illogical sequence, a limited vocabulary, a lack of mechanical understanding, inexplicitness issues, and grammatical errors.

In addition, some studies looked into students' challenges in composing recall texts. Students' problem in creating recount text, according to Harris, Ansyar, and Radjab (2014, p.24), is in using language features. The employment of the simple past tense, action verb, connecting verb, and pronoun all contribute to this issue. Husna and Multazim (2019, p. 30) go on to say that the student's difficulties in creating recount text were related to content, organization, language, mechanics, and generic structure, particularly in terms of orientation and reorientation. Finally, students struggle with linguistic characteristics, general structure, and areas of writing that must be considered, such as content, organization, syntax, and mechanics. Furthermore, Mustika, Udin, and Susanti (2020, p.1) elaborate on the students' difficulties are in terms of content, organization, vocabulary, and sentence structure. These difficulties are particularly encounter when writing a recount text. Having a lack of vocabulary can make students stuck on doing writing activities. Not only that, the organization of recount text or commonly known as its generic structure also can hinder students to produce their well-organized recount text. Moreover, less ability to write grammatical sentences can make students frustrated in the writing process. 
Based on previous explanations, this research investigated students' difficulties in writing a recount test at eighth-grade students of SMP Bait Quran.

\section{RESEARCH METHOD}

The research method employed a descriptive qualitative research. According to Creswell (2014, p. 33), qualitative research is a way to examine and comprehend the meaning that individuals or groups attribute to a social or human situation. Emerging questions and processes are part of the research process, as are data acquired in the participant's environment, data analysis that builds inductively from specifics to extensive topics, and the researcher's interpretations of the information.

The research subjects were the eighth-graders at SMP Bait Al-Qur'an Kayuagung, which had a total of 22 students in the academic year 2020/2021. To gather the data, a writing test and interviewing were applied. The data were analyzed using qualitative analysis namely, data reducing, data displayed, content analysis, and drawing a conclusion. To check the trustworthiness of the data, a triangulation method was utilized.

\section{RESULTS AND DISCUSSION}

The students' writing test were scored based on the rubric that covers content, organization, vocabulary, grammar, and mechanics. The detailed information are as follows.

In terms of content, most students were in very poor category. It can be seen in Table 1 stated that no student was in excellent, 5 students $(22.73 \%)$ were in good to average, 5 students $(22.73 \%)$ were in fair to poor, and 12 students $(54.54 \%)$ were in very poor.

Table 1. Students' Score in Content Writing Recount Text

\begin{tabular}{|c|c|c|c|}
\hline $\begin{array}{l}\text { Aspect of Scoring } \\
\text { Writing Test }\end{array}$ & Category & Frequency & Percentage \\
\hline \multirow{4}{*}{ Content } & Excellent & 0 & $0 \%$ \\
\hline & Good to Average & 5 & $22.73 \%$ \\
\hline & Fair to Poor & 5 & 22.73 \\
\hline & Very Poor & 12 & $54.54 \%$ \\
\hline Total & & 22 & $100 \%$ \\
\hline
\end{tabular}

In terms of organization, most students had very poor ability in determining the organization of the text. It can be seen in Table 2 stated that no student was in excellent, 2 students $(9.09 \%)$ were in good to average, 5 students $(22.72 \%)$ were in fair to poor, and 15 students $(68.18 \%)$ were in very poor.

Table 2. Students' Score in Organization Writing Recount Text

\begin{tabular}{clcc}
\hline $\begin{array}{l}\text { Aspect of Scoring } \\
\text { Writing Test }\end{array}$ & Category & Frequency & Percentage \\
\hline \multirow{4}{*}{ Organization } & Excellent & 0 & $0 \%$ \\
& Good to Average & 2 & $9.09 \%$ \\
& Fair to Poor & 5 & $22.72 \%$ \\
& Very Poor & 15 & $68.18 \%$ \\
\hline Total & & $\mathbf{2 2}$ & $\mathbf{1 0 0} \%$ \\
\hline
\end{tabular}

In terms of vocabulary, students had poor ability in determining the vocabulary of the text. 
It can be seen in Table 3 stated that no student was in excellent, 1 student $(4.55 \%)$ was in good to average, 9 students $(40.91 \%)$ were in fair to poor, and 12 students $(54.54 \%)$ were in very poor.

Table 3. Students Score in Vocabulary Writing Recount Text

\begin{tabular}{clcc}
\hline $\begin{array}{c}\text { Aspect of Scoring } \\
\text { Writing Test }\end{array}$ & Category & Frequency & Percentage \\
\hline \multirow{4}{*}{ Vocabulary } & Excellent & 0 & $0 \%$ \\
& Good to Average & 1 & $4.55 \%$ \\
& Fair to Poor & 9 & $40.91 \%$ \\
& Very Poor & 12 & $54.54 \%$ \\
\hline
\end{tabular}

In terms of grammar, students had poor ability in determining the vocabulary of the text. It can be seen in Table 4 stated that no student was in excellent and good to average, 3 students $(13.63 \%)$ were in fair to poor, and 19students $(86.37 \%)$ were very poor.

Table 4. Students' Score in Grammar Writing Recount Text

\begin{tabular}{|c|c|c|c|}
\hline $\begin{array}{l}\text { Aspect of Scoring } \\
\text { Writing Test }\end{array}$ & Category & Frequency & Percentage \\
\hline \multirow{4}{*}{ Grammar } & Excellent & 0 & $0 \%$ \\
\hline & Good to Average & 0 & $0 \%$ \\
\hline & Fair to Poor & 3 & $13.63 \%$ \\
\hline & Very Poor & 19 & $86.37 \%$ \\
\hline Total & & 22 & $100 \%$ \\
\hline
\end{tabular}

In terms of mechanics, students had poor ability in determining the mechanics of the text. It can be found in Table 1 stated that no student was in excellent and in good to average, 6 students $(27.28 \%)$ were in fair to poor, and 16 students $(72.72 \%)$ were in very poor.

Table 5. Students' Score in Mechanics Writing Recount Text

\begin{tabular}{clcc}
\hline $\begin{array}{c}\text { Aspect of Scoring } \\
\text { Writing Test }\end{array}$ & \multicolumn{1}{c}{ Category } & Frequency & Percentage \\
\hline \multirow{3}{*}{ Mechanics } & Excellent & 0 & $0 \%$ \\
& Good to Average & 0 & $0 \%$ \\
& Fair to Poor & 6 & $27.28 \%$ \\
& Very Poor & 16 & $72.72 \%$ \\
\hline Total & & $\mathbf{2 2}$ & $\mathbf{1 0 0} \%$ \\
\hline
\end{tabular}

The following graph depicts the dispersion of students' percentages of difficulty in producing recount text.

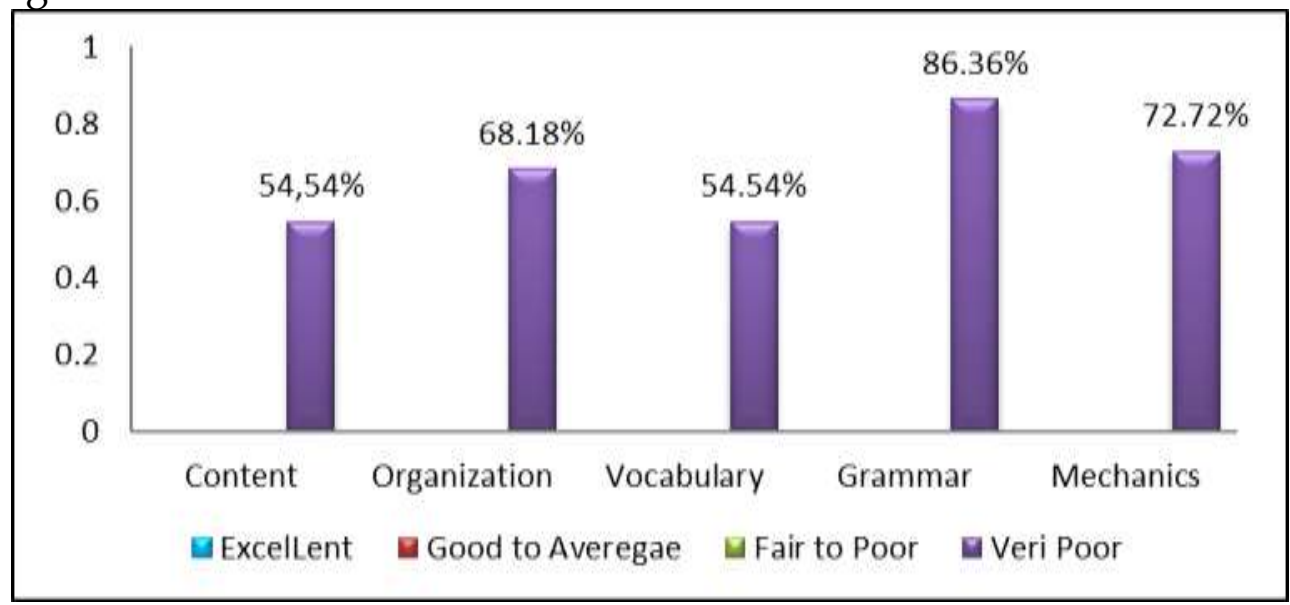


Figure 1 revealed that most students struggled to write recall text. There were 12 students $(54.54 \%)$ who were extremely poor in writing recount text content, 15 students $(68.18 \%)$ who were extremely poor in writing recount text organization, 12 students $(54.54 \%)$ who were extremely poor in vocabulary, 19 students $(86.36 \%)$ who were extremely poor in grammar, and 16 students $(72.72 \%)$ who were extremely poor in mechanics. It was discovered that the majority of students had very weak grammatical skills when composing a recount text.

The questionnaire was given to obtain students' difficulty in recount text. The students had to choose Yes or No to answer the questions on the questionnaire, which had ten in total. Table 6 displays the results of the interview.

Table 6. Percentages of Students ' Interview

\begin{tabular}{|c|c|c|c|c|c|}
\hline \multirow[b]{2}{*}{ No } & \multirow[b]{2}{*}{ Questions Item } & \multicolumn{4}{|c|}{ Percentages of Students' Answer } \\
\hline & & $\begin{array}{l}\text { Number } \\
\text { of } \\
\text { Students } \\
\text { (Yes) }\end{array}$ & Percentages & $\begin{array}{l}\text { Number of } \\
\text { Students } \\
\text { (No) }\end{array}$ & Percentages \\
\hline 1. & $\begin{array}{l}\text { Do you have difficulty } \\
\text { in grammar use of } \\
\text { recount text? }\end{array}$ & 19 & $86.37 \%$ & 3 & $13.63 \%$ \\
\hline 2. & $\begin{array}{l}\text { Do you know about } \\
\text { grammar use in } \\
\text { recount text? }\end{array}$ & 12 & $54.55 \%$ & 10 & $45.45 \%$ \\
\hline 3. & $\begin{array}{l}\text { Do you understand } \\
\text { about recount text? }\end{array}$ & 6 & $27.28 \%$ & 16 & $72.72 \%$ \\
\hline 4. & $\begin{array}{l}\text { Do you have difficulty } \\
\text { in understanding } \\
\text { recount text? }\end{array}$ & 18 & $81.81 \%$ & 4 & $18.19 \%$ \\
\hline 5. & $\begin{array}{l}\text { Is it necessary to have } \\
\text { knowledge and } \\
\text { experience in writing } \\
\text { recount text? }\end{array}$ & 18 & $81.81 \%$ & 4 & $18.19 \%$ \\
\hline 6. & $\begin{array}{l}\text { Do you have enough } \\
\text { knowledge to write } \\
\text { recount text? }\end{array}$ & 12 & $54.55 \%$ & 10 & $45.45 \%$ \\
\hline 7. & $\begin{array}{l}\text { Do you like writing } \\
\text { recount text? }\end{array}$ & 5 & $22.72 \%$ & 17 & $77.28 \%$ \\
\hline 8. & $\begin{array}{l}\text { Do you often write } \\
\text { recount text? }\end{array}$ & 0 & $0 \%$ & 22 & $100 \%$ \\
\hline 9. & $\begin{array}{l}\text { Do you understand } \\
\text { about recount text that } \\
\text { have been taught? }\end{array}$ & 4 & $18.19 \%$ & 18 & $81.81 \%$ \\
\hline 10. & $\begin{array}{l}\text { Does the teacher } \\
\text { explain the material } \\
\text { clearly? }\end{array}$ & 3 & $13.63 \%$ & 19 & $86.37 \%$ \\
\hline
\end{tabular}

Based on Table 6, for the first question, 19 students $(86.37 \%)$ had difficulties in using grammar and 3 students $(13.63 \%)$ had no difficulties in using grammar to write a recount text. For the second question, 12 students (54.54\%) knew about grammar use and 10 students $(45.45 \%)$ did not know about grammar use in a recount text. For the third 
question, 6 students (27.28\%) did not understand and 16 students $(72.72 \%)$ understood a recount text. For the fourth question, 18 students $(81.81 \%)$ faced difficulties and 4 students $(18.19 \%)$ did not face difficulties in understanding a recount text. For the fifth question, 18 students $(81.81 \%)$ stated that it was necessary to get knowledge and experience and 4 students $(18.19 \%)$ stated that it was not necessary to get knowledge and experience in writing a recount text. For the sixth question, 12 students $(54.54 \%)$ said that they had enough knowledge and 10 students $(45.46 \%)$ said that they had not enough knowledge to write a recount text. For the seventh question, 5 students $(22.72 \%)$ liked writing and 17 students $(72.28 \%)$ did not like writing a recount text. For the eighth question, 22 students $(100 \%)$ said that they never wrote and no students often wrote a recount text. For the ninth question, 4 students $(18.19 \%)$ comprehended a recount text taught by the teacher and 18 students $(81.81 \%)$ did not understand it. For the tenth question, 3 students $(13.63 \%)$ stated that they could understand the material explained by the teacher and 19 students $(86.37 \%)$ stated that they could not understand it.

The results of students' recount text writing revealed that the majority of pupils had difficulty creating a recount text. The majority of students received a low grade in writing a recount text, which was categorized as very poor. It can be deduced from the results of the five components of writing listed in the writing rubric results of students' recount text writing revealed that the majority of pupils had difficulty creating a recount text. The majority of students received a low grade in writing a recount text, which was categorized as very poor. It can be deduced from the results of the five components of writing listed in the writing rubric.

First, students' challenges were discovered to be in the subject area, with total percentages of $54.54 \%$ falling into the "extremely poor" group. According to the researcher's observations, the students were still unsure about how to pursue their idea in writing a recount text. Their writing had a different tone from the title. They were unable to develop their ideas. Husna and Multazim (2019, p.70) argue that learners had problems in content component because they lacked of ideas to write the story and only wrote in one paragraph and were also confused about it so as to write inappropriate content of a recount text.

Second, students' challenges were in the area of organization, with a total percentage of $68.18 \%$ falling into the "extremely poor" category. The formation of a logical sequence of events was the organization aspect criteria, according to Jacob et. al, grading's rubric in Weigle (2002, p.5). It meant that this feature was linked to the recount text's generic structure. As a result, most of students did not write the recount text sequently.

Third, students had difficulty with vocabulary, with a total proportion of $54.54 \%$ falling into the very poor category. It was discovered that students utilized certain incorrect terminology to express their ideas based on their writing. Since the students did not read many books, their vocabulary for writing recount texts did not improve.

Fourth, students had the most difficulty with grammar, with an overall proportion of $86.36 \%$ falling into the "extremely poor" group. Since a recount text was retold about something that has previously happened in the past, students should write the paragraph in the past tense, according to grammatical faults. The majority of students continued to compose recall text paragraphs in the present tense due to confused about grammar use in writing recount text. Harris, Ansyar, Radjab (2014, p.62) declared that students' difficulties 
in writing because of problems in intralingual transfer. It had to do with the students' ability to use the right grammar, as well as their lack of grammatical expertise, which caused them to make numerous errors in their writing.

Fifth, students had difficulty in the mechanics' area, with a total proportion of 72.72 percent falling into the "very poor" group. The majority of students, according to the study, did not pay attention to capitalization, punctuation, or spelling. Za'in (2017, p.23) agrees, stating that mechanics is one of the challenges with writing. The usage of the language's graphic conventions, including capitalization, spelling, paragraphing, and punctuation, is known as mechanics.

Furthermore, as a consequence of the above-mentioned interview, it was discovered that various issues led pupils to have difficulty. First, there was a grammatical problem; most students had trouble using language in recount texts because they were unfamiliar with how to use grammar in a recount text. Then there's a lack of understanding of the recount text. The majority of students had never heard of recount text. They had trouble comprehending the narrative text itself. They couldn't grasp a recount text, even after the teacher explained it to them. Finally, less writing practice. The majority of students never produce a recount text because they dislike writing in English, especially recount texts.

Based on the foregoing explanation, it can be determined that the most difficult component of producing a recall narrative for students was the grammar aspect. In creating a recount text, 19 students $(86.37 \%)$ were unsure how to employ language. It was connected to the interview findings, which revealed that most students struggled to write a recount text because they struggled to comprehend how to utilize grammar in a recount text. They also lacked information about recount texts and had little experience writing them.

\section{CONCLUSION AND SUGGESTIONS}

Students in the eighth grade at SMP Bait Al-Qur'an Kayuagung had difficulty producing a recount text. According to the collected data and the results of students' recount text writing, the majority of students had difficulty producing a recount text. It was clear from the results that the majority of students struggled to write a recount paragraph. 12 students $(54.54 \%)$ were very poor in content, 15 students $(68.18 \%)$ were very poor in an organization, 12 students $(54.54 \%)$ were very poor in vocabulary, 19 students $(86.37 \%)$ were very poor in grammar, and 16 students $(72.72 \%)$ were very poor in a mechanic. It happened because most students struggled to understand how to utilize language in a recall text. They also lacked expertise on how to write a recount text and had no experience doing it. Teachers, students, and other researchers are provided with some recommendations. It is expected of the teacher to educate students on how to enhance their capacity to write recount texts, particularly skills and techniques in writing tests, in order to assist students in overcoming obstacles in writing text. To increase learners' writing skills, the teacher should present engaging material. Furthermore, teachers should use a variety of teaching tactics while teaching writing skills, such as creating recount text, in order to obtain greater results. Students should study more about writing recount texts, such as writing skills, writing techniques, and test-taking procedures for writing tests, which will be helpful when dealing with writing tests. They should also practice writing on a regular basis to ensure that they have a dependable understanding and are familiar with a writing test. As a result, the learners' challenges in writing subjects can be reduced. This research 
can be used as a reference for future research on sorts of errors based on the expertise of others. The goal of this study is to provide support for other studies and to find solutions to errors committed by Indonesian students.

\section{REFERENCES}

Azhar, S.(2015). Analysis of generic structure of recount texts (the study of fourth semester students of stain Salatiga in the academic year of 2012/2013). Retrieved from http:/ / erepository.perpus.iainsalatiga.ac.id/324/1/Syaiful\%20Alazar_11307131.pdf

Bazir, A, H. (2016). The role of writing diary in a classroom. International Journal of Research in Linguistics, Language Teaching and Testing, 1(1), 82-88. Retrieved from http:/ /ijrlltt.com/fulltext2/ paper-28102016213657.pdf.

Brink, S. (2020). The importance of writing skills. Retrieved from https:/ / epale.ec.europa.eu/en/blog/importance-writing-skills.

Creswell, J, W. (2014). Research design, qualittative, quantitave, and mixed methods approaches ( $4^{\text {th }}$ ed). Boston: Pearson Education. Retrieved from http:/ / basu.nahad.ir/uploads/creswell.pdf.

Harris, A., Ansyar, M.,\& Radjab, D. (2014). An analysis of students' difficulties in writing recount text at tenth grade of SMA N 1 Sungai Limau. Journal English Language Teaching (ELT) 2(1): 55-63.

Husna, A., \& Multazim, A. (2019). Students' difficulties in writing recount text at inclusion classes. LET: Linguistics, Literature and English Teaching Journal 9 (1): 52-76.

Mustika, H, Y., Udin, U., \& Susanti, N, W, M. (2020). An analysis of students' difficulties in writing recount text: A case study at the eleventh grade students of ma putra al-ishlahuddiny Kediri academic year 2016/2017. Indonesian Journal of Teacher Education, 1(1), 1-10. Retrieved from https://journal.publicationcenter.com/index.php/ijte/article/view/23.

Sapkota, A. (2012). Developing students' writing skill through peer and teacher correction: an action research. Journal of Nelta, 17,70-82.

Sari, M.K. (2017). An analysis of students' problem in writing recount text. Journal of Educational Studies, $\quad 4(1)$ Retrieved from https:/ / ejournal.iainbukittinggi.ac.id/index.php/educative/article/view/316.

Weigle, S. C. (2002). Assessing writing. Cambridge: Cambridge University Press.

Za' in, L,D. (2017). An investigation of students' problem in writing recount text at the first semester of the eighth grade of SMPN 4 Bandar Lampung in the academic year of 2016/ 2017. Retrieved

from http:/ / repository.radenintan.ac.id/793/1/SKRIPSI_DIANA.pd 